\title{
The Theory and Practice of Hadith Criticism in the Mid-Ninth Century
}

\author{
Christopher Melchert
}

For some time, I have suspected that there were two approaches in the ninth century to sifting hadith. One was followed, usually without express theorizing, by Sunni collectors and critics, with stress on isnād comparison. The other was elaborated by early rationalists, with stress on the personal probity of informants, likening them to witnesses whose testimony is accepted in court. However, it has transpired that there was actually not one identifiable position but a spectrum of opinion among the ninth-century Mu'tazila, although none were so heavily reliant on isnād comparison as the Sunni collectors and critics. Insofar as there was any Hanafi theory of hadith, it did resemble Mu'tazilì theory, probably more primitivist than rationalist. At the other end of the spectrum, there was a Sunni position of complete reliance on isnād comparison. However, as with the Mu'tazila, there turns out to have been not one identifiable position but a spectrum of opinion among the ninth-century Sunnis, with the preponderant position not at the extreme but ultimately for relying less heavily on isnād comparison than on felt consensus.

\section{$1 \quad$ Early Sunni Theory and Practice}

Modern hadith scholarship has long depended on medieval hadith scholarship. James Robson published a translation of a short survey by al-Hākim alNaysābūrī (d. Nishapur, 405/1014). ${ }^{1}$ But there has been a lamentable tendency for modern scholars to start with theoretical descriptions of the eleventh to thirteenth centuries. In consequence, descriptions of hadith criticism from most of the twentieth century do not well match such works of criticism as survive from actual Sunni hadith collectors of the ninth century. (This is not to

1 Al-Ḥākim al-Naysābūrī, An Introduction to the Science of Tradition: Being Al-madkhal ilā márifat al-Iklīl, ed. and trans. James Robson, Oriental Translation Fund, n.s., 39 (London: Luzac and Co., 1953). 
deny that theoretical descriptions of the eleventh to thirteenth centuries are worth studying for themselves. ${ }^{2}$ ) For example, here is James Robson on the biographical literature:

As a result of the effort to investigate the genuineness of traditions biographical works were compiled regarding the people who appear in is$n \bar{a} d s$. It was important to know the years of their birth and death, for this shows whether they could have met the people they are said to have quoted. Statements were also recorded regarding the degree of their trustworthiness, but these raised problems for they were frequently contradictory. ${ }^{3}$

To the contrary, it turns out that the massive biographical dictionary of the famous collector and critic al-Bukhārī (d. Khartang, near Samarqand, 256/870), alTärïkh al-Kabīr, almost never mentions anyone's date of birth (none was found in a sample of 200), seldom anyone's date of death (6 percent of the sample), and equally seldom evaluations of men's trustworthiness ( 6 percent). ${ }^{4}$ Its evident purpose was to identify names in asānìd.

Actually, the stress on dates so prominent in the modern secondary literature generally seems to characterize not so much the hadith as the adab approach, represented in the ninth century above all by Ibn Sa'd (d. Basra, 230/845). Perhaps dates are an example of the miscellaneous knowledge it so prized. We should probably associate Ibn Sacd's interest in dates first with his interest in who did or did not dye his hair, as similar miscellany, not with his unsystematic interest in evaluations of traditionists. The hadith critics could hardly know dates of birth and death with anything like certainty, anyway. For some prominent figures, we do have precise dates; for example, that alḤasan al-Bașrī died in Rajab 110, or even 1 Rajab/10 October 728, Muhammad b. Sīrīn 100 days later (12 Shawwāl) or more precisely g Shawwāl 110/15 January 729. ${ }^{5}$ But for many more prominent figures, the sources provide multiple dates.

2 See Asma Hilali, "Muslim Tradition: Theory vs Usage," elsewhere in this volume, for some later theorists' struggle to synthesize the professed practice of an earlier century.

3 James Robson, s.v. "Hadìth," in Encyclopaedia of Islam, 2nd ed., vol. III (Leiden: Brill, 1971), 836.

4 Christopher Melchert, "Bukhārī and Early Hadith Criticism," Journal of the American Oriental Society 121 (2001): 10-12. Even fewer dates are offered by, among others, al- Ijlì (d. 261/874-875), Tārīkh al-Thiqāt, and Ibn Abī Ḥātim (d. 327/938), al-Jarḥ wa-al-Tádìl.

5 Aḥmad b. Ḥanbal, Kitāb al-'Tlal wa-Ma'rifat al-Rijäl, ed. Wașī Allāh b. Muhammad 'Abbās, 4 vols (Beirut: al-Maktab al-Islāmī, 1988), 1:308, 3:182 = ed. Muḥammad Ḥusām Bayḍūn, 2 vols 
Ibn Hajar mentions from several sources that al-Awzā̄i died in 151, 155, 156, and 158, to which is to be added Ibn Sa'd's date of $157 \cdot{ }^{6} \mathrm{Ibn}$ Sa'd declares unanimous agreement that Sufyān al-Thawrī died in Sha'bān 161/May-June 778, but Yahyyā b. Saīì al-Qatțān (d. 198/813) and Ahmad b. Ḥanbal (d. 241/855) are quoted as saying rather he died in the beginning of that year/autumn 777 , Khalifa b. Khayyāt (d. 240/854-855?) lists him among those who died in the year 162, and al-'Tjli reports the years 157,159 , and $161 .^{7}$ Dates were evidently inferred from asānìd - who managed to meet whom-, and early hadith critics were right not to treat them as independent information. ${ }^{8}$

More recently, Eerik Dickinson has stressed isnād comparison alone. If a hadith report was supported by multiple, mutually corroborative asānìd, according to his summary, it must be sound. If a particular link was without parallels, one investigated whether the transmitter's hadith were usually corroborated or not. If they were, he got the benefit of the doubt in this case; if not, then this uncorroborated report must be considered weak and the transmitter became suspect. Biographical information, such as reports of personal character, was supplementary at best. ${ }^{9}$

The earliest extant theoretical discussion of hadith criticism I know of is from al-Shāfici (d. Old Cairo, 204/820) in his introductory survey of jurisprudence, al-Risāla. ${ }^{10}$ On the problem of accepting an uncorroborated hadith report (khabar al-wāhid), he says this:

(Beirut: Mu’assasat al-Kutub al-Thaqāfiyya, 1410/199o), 1:126, 2:15o; Ibn Sacd, Biographien, ed. Eduard Sachau et al., 9 vols in 15 (Leiden: Brill, 1904-1940), 7/1:129 = 9 vols (Beirut: Dār Șādir, 1957-1968), 7:177.

6 Ibn Ḥajar, Tahdhīb al-Tahdhīb, 12 vols (Hyderabad: Majlis Dāirat al-Macāif al-Niẓāmiyya, 1325-1327, repr. Beirut: Dār Șādir, n.d.), 6:240, 242; Ibn Sa'd, Biographien, 7/1:185 = (Beirut) 7:488.

7 Ibn Sa'd, Biographien, 6:258 = (Beirut) 6:371; Ibn H̦anbal, Ilal, 2:365 = ed. Bayḍūn, 1:328; Khalīfa b. Khayyāț, al-Tārīkh, ed. Suhayl Zakkār, Ihyyā̄ al-Turāth al-Qadīm 19, 2 vols. (Damascus: Wizārat al-Thaqāfa, 1968), 2:686; al-Ijlī, Tārīkh al-Thiqāt, arr. Ibn Ḥajar al-Haythamī, ed. 'Abd al-Mu'țī Qal'ajī (Beirut: Dār al-Kutub al-'Ilmiyya, 1405/1984), 193.

8 "When later biographical works give dates of death that are not found in earlier biographers, it usually is safe to assume that those dates were not traditional but the result of later scholarly reconstruction. This applies, in particular, to dates referring to persons who lived during the first two centuries of the Muslim era": so Franz Rosenthal, A History of Muslim Historiography, 2nd rev. ed. (Leiden: Brill, 1968), 14n.

9 Eerik Dickinson, The Development of Early Sunnite hadīth Criticism, Islamic History and Civilization, Studies and Texts 38 (Leiden: Brill, 20o1), chap. 6.

10 See now Belal Abu-Alabbas, "The Principles of Hadith Criticism in the Writings of alShāfi'ì and Muslim," Islamic Law and Society 24 (2017): 311-325. 
We do not accept hadith-reports from those hadith-transmitters who err frequently and have no accurate notes on which to rely, just as we do not accept the testimony of those who make frequent errors when giving evidence.

Specialists in hadith-reports are of different kinds. Some among them are well known for their knowledge of hadith-reports, for seeking it out as a matter of piety, learning it from fathers, uncles, relatives, and friends, and for spending much time in sessions with those who debate about it. Such persons are to be given preference in respect of their ability to memorize. If such a person is contradicted by someone who falls short of him, it is better to accept the hadith-reports of the former than those of the one who, being among those who fall short of him, contradicts him.

One must also evaluate specialists in hadith-reports according to certain considerations. If they share in transmitting hadith-reports from one man, then one can draw an inference about the strength of their memory according to whether their report agrees with what others have memorized from that person, or one draws an inference against the strength of their memory if they go against what others have memorized from him. In the case of inconsistent narrations, one draws an inference regarding what has been correctly memorized and what is an error by this means. Other things, too, indicate veracity, sound memory, and error .$^{11}$

Al-Shāfíi is evidently arguing against people who reject hadith vouched for by only one transmitter. Hadith transmission should be like testimony in a court of law, they hold, where a fact is established by two jurors, not one only. (Most of this chapter of the Risāla is devoted to the differences between testimony and hadith transmission.) Al-Shāfi ì needs a less strict standard in order for his scheme of depending on hadith to interpret the Qurān to be feasible. He offers historical examples of Companions' acting on information from a single informant, then, as here, means of identifying those single informants who should be trusted. Preferably, X's report from A is corroborated by Y and Z's relating the same thing. But X's uncorroborated report from A may still be probative if it can be shown that at least X's reports from B, C, and D are corroborated by Y and Z's reports from them.

11 Al-Shāfi'ì, The Epistle on Legal Theory, ed. and trans. Joseph E. Lowry, Library of Arabic Literature (New York: New York University Press, 2013), 276-279. 
The first collector and critic from whom we have a systematic description of hadith criticism is Muslim (d. Nishapur, 261/875), mainly the introduction to al-Jāmi al-Sahịh. He speaks of three categories, evidently strong, mediocre, and weak:

As for the first subdivision ..., their transmitters should be people of integrity and precision in transmitting traditions, people whose transmitted material is void of serious controversy or excessive confusion .... We shall follow them up by traditions in the isnāds of which occur people who, unlike the category [of transmitters] hitherto presented, are not credited with the [same] memory and precision. ${ }^{12}$

Befitting an introduction, this refers to Muslim's practice in the Jāmi to come of presenting multiple variants one after another, starting with the strongest, evidently meaning the least controversial. The way to determine classifications is evidently isnād comparison:

The characteristic of munkar in the traditions of a [certain] transmitter is that, after a comparison is made, his riwāya (= transmission) contradicts, or-in any case-hardly corresponds with, the riwayya of other transmitters who have satisfactory memories. If the majority of such a transmitter's traditions is of this sort, they are left out of consideration, they will not be accepted, nor will they be put to any use..$^{13}$

(Juynboll has just translated munkar as "rejected.") This is not essentially different from al-Shāfiì's formulation. However, Muslim seems to put a little more stress on isnäd comparison, as described by Dickinson, less on biographical data: there is nothing here like al-Shāfi'i's call for "well known for their knowledge of hadith-reports, for seeking it out as a matter of piety," and so on ("people of integrity" translates Muslim's ahl al-istiqāma). Neither al-Shāfi'i nor Muslim mentions dates of birth and death. Muslim seems less anxious to defend the uncorroborated report; however, he implicitly accepts it when everyone in the isnād normally has his hadith matched by what others transmit from the same sheikhs.

We have no systematic description of hadith criticism from al-Bukhārī, but here is a sample reported by his sometime disciple al-Tirmidhī (d. 279/892):

12 Gautier H.A. Juynboll, "Muslim's Introduction to His Șaḥih," Jerusalem Studies in Arabic and Islam 5 (1984): 267 .

13 Juynboll, "Muslim's Introduction," 269. 
I asked Muhammad [b. Ismā'il al-Bukhārī] about the hadith report of Ibn Abī Dhi'b < Makhlad b. Khufāf < 'Urwa < 'Ā'isha that the yield goes with the guaranty (al-kharäj bi-al-damān). He said, "Makhlad b. KhufäfI know of no hadith of his other than this one, which is disreputable." I asked him about the hadith report of Hishām b. "Urwa < his father < 'Ā'isha. He said, "Only Muslim b. Khālid al-Zanjī related it. Muslim does away with hadith." I told him, "Umar b. 'Alī related it < Hishām b. 'Urwa." He did not recognize it as belonging to the hadith of 'Umar b. 'Alī. I asked him, "Do you think 'Umar b. 'Alī concealed some defect in it (dallasa fìh)?" Muhammad said, "I do not know that 'Umar b. 'Alī concealed defects." I told him that Jarīr related it < Hishām b. 'Urwa. He said, "Muhammad b. Humayd said that Jarīr related this in debate (munāzara). They do not know that he ever heard it." Muhammad considered the hadith report of Hishām b. 'Urwa concerning this topic to be weak..$^{14}$

In effect, al-Bukhārī adduces four arguments to discredit the quoted hadith report. First, it is from someone whose general reliability could not be tested ("I know of no hadith of his other than this one"). Secondly, if it has been corroborated, it is by someone known to make things up (Muslim b. Khālid al-Zanji15), or, thirdly, if it has been corroborated, it is by a hadith report he has never heard of before or, fourthly, by a hadith report known to have been related only in the course of a debate, when the temptation must have been great to invent supporting evidence, not in the course of a formal session of dictation. Al-Bukhārì's technique apparently conforms to al-Shāfi'ìs theory, at least inasmuch as Makhlad b. Khufāf falls short of being one of those "well known for

14 Al-Tirmidhī, 'Tlal al-Tirmidhī al-Kabīr, arr. Abū Ṭālib al-Qāḍī, ed. Șubhī al-Sāmarrāīì, Abū al-Macậ̂̄ al-Nūrī and Mahmūd Muḥammad Khalīl al-Ṣacīì̄ (Beirut: 'Ālam al-Kutub and Maktabat al-Nahḍa al-'Arabiyya, 1409/1989), 191-192, nos. 337-338. In his Jāmic', Tirmidhī includes this hadith report, calling it hasan șahịh. He goes on to say, "Practice goes by this according to the people of knowledge" (more below on such appeals to consensus): al-

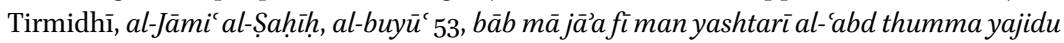
bihi 'ayban, no. 1285. It is also reported by Abū Dāwūd, al-Sunan, al-buyū' 71 , fi man ishtarā 'abdan fa-ista'malahu thumma wajada bihi 'ayban, no. 3510, al-Nasā̄ì, al-Mujtabāa, al-buyū' 15, al-kharāj bi-al-ḍmān, no. 4495, and Ibn Māja, al-Sunan, al-tijārāt 43, bāb al-kharāj bial-d̦amān, no. 2242. Al-Tirmidhī also provides a clear explanation of the legal application: "As for the meaning of al-kharāj bi-al-damān, it is that a man purchases a slave and uses him, then finds some fault in him and returns him to the seller. The produce (of his labour) belongs to the buyer, since if the slave had perished, it would have been a loss to the buyer's property. In questions like this, the yield goes with the guaranty" (loc. cit.).

15 On Muslim b. Khālid al-Zanjī (d. Mecca, 18o/796-797?), alleged Qadari, see Ibn Ḥajar, Tahdhīb, 10:128-130. 
their knowledge of hadith-reports, for seeking it out as a matter of piety, learning it from fathers, uncles, relatives, and friends, and for spending much time in sessions with those who debate about it"; but al-Bukhārī the expert hadith critic probably put more emphasis on Makhlad's association with uncorroborated reports. (Sharing the doubts of al-Bukhārī and other critics concerning Makhlad b. Khufāf, Juynboll assigns this hadith report to the one who reported it on his authority, Ibn Abī Dhi'b [Medinese, d. Kufa, 159/775-776]. To a modern scholar's mind, the literary form of different versions, "variously worded preambles ... followed by a concise legal maxim," raises additional doubts, but al-Bukhārī is notably indifferent. ${ }^{16}$ ) Many other examples are to be found of alBukhārīs rejecting a hadith report for lack of corroboration.

Outright contradiction comes up less often but here is an example of it, concerning the hadith report < Nașr b. 'Alī al-Jahḍamī < Bishr b. 'Umar < Shu'ayb b. Ruzayq, Abū Shayba < 'Ațā' al-Khurāsānī < 'Ațā' b. Abī Rabāh < Ibn 'Abbās < the Messenger of God: "Two eyes that the Fire will not touch are an eye that has wept from the fear of God and an eye that has stayed awake on watch in the path of God":

"I asked Muhammad about this hadith report. He said, 'Shu'ayb b. Ruzayq is a mediocre traditionist (muqārib al-hadīth), but the matter is with 'Ațā' al-Khurāsānī. I do not know that Mālik b. Anas has a man Mālik relates from whose hadith deserves to be left other than 'Ațā' al-Khurāsānī.' I asked him, 'What is the matter with him?' He said, 'Most of his hadith are turned upside down. He related $<\mathrm{Sa}^{\top} \mathrm{i} d \mathrm{~b}$. al-Musayyab that a man came to the Prophet ... and broke the Ramadan fast. One of the disciples of Sa'id $b$. al-Musayyab said, "I asked Saīd about this hadith report. He said, "Atạa' has ascribed a lie to me. I did not relate it this way." 'Atạa' related < Abū Salama < 'Uthmān and Zayd b. Thābit concerning al-ïlā', 'When four months have elapsed, it is a divorce that requires separation (tațliqa bä̀ina).' Habīb b. Abī Thābit related < Tâ̄wūs < 'Uthmān that he said of the client that he may be made a charitable foundation (yūqaf). 'Ațā' related < Sa'īd b. alMusayyab, 'When he stands up four times, he prays four times.' Dāwūd b. Abī Hind related from Sa'īd b. al-Musayyab other than that." I said to him, "Qatāda related that Saî̀ b. al-Musayyab said, 'When he stands up four times, he prays four times,' just as 'Ațâ̄ related it." Muhammad said, "I think Qatāda took it from 'Ațāa.."17

16 Gautier H.A. Juynboll, Encyclopedia of Canonical Haditth (Leiden: Brill, 2007), 212. For the evaluations of medieval critics, see Ibn Ḥajar, Tahdhïb, 10:74-75.

17 Tirmidhī, Tlal, 271-273, nos. 495-50o. 
Al-Bukhārî's case against 'Ațā' is that various other traditionists related something else from Sa'īd b. al-Musayyab than what 'Atạa' did; that is, X's report from A is contradicted by Y and Z's reports from him. (At the end, Bukhārī brushes off apparent corroboration from Qatāda with the argument that this is really sideways growth. ${ }^{18}$ ) The example illustrates al-Shāfi'i's rule, "If they share in transmitting hadith-reports from one man, then one can draw an inference about the strength of their memory according to whether their report agrees with what others have memorized from that person." (Al-Tirmidhī himself adds, "Ațā̄ al-Khurāsānī is a trustworthy man. Trustworthy imams related from him, such as Mālik, Ma'mar, and others. I have not heard that any of the early [critics] aspersed him for anything." So he is unconvinced by Bukhāri’s case against 'Ațā'. He includes the hadith report about the two eyes in his Jāmi', where he calls it hasan gharïb, "sound although uncorroborated."19)

I have noticed just one example (out of 717 comments in al-Tirmidhi's collection) of al-Bukhārī's disqualifying a hadith report because of someone's date of birth: "I asked Muhammad about 'Alqama b. Wāil, whether he heard from his father. He said, 'He was born after his father's death by six months." ${ }^{20}$ In alTārīkh al-Kabīr, al-Bukhārī says to the contrary that 'Alqama b. Wāìl heard from his father (sami'a abāh $)$ without further comment, and al-Tirmidhī has several hadith reports in al-Jāmi' al-Șahịh with the link 'Alqama b. Wā'il $<$ his father in the isnād, including the very one about which al-Bukhārī complains in the Ilal, which he calls hasan șahih ("good and sound"). ${ }^{21}$ It is apropos of another, related report in al-Jāmic that al-Tirmidhī quotes al-Bukhārī, "Abd al-Jabbār b. Wāil b. Hujr did not hear from his father or meet him. It is said that he was born some months after his father's death."22 In al-Tārīkh al-Kabìr, al-Bukhārī quotes a Muhammad b. al-Ḥujr concerning 'Alqama's brother 'Abd al-Jabbār b. Wāil (d. 112/730-731), "He was born after his father by six months," presumably meaning "after his father's death."23 Ibn Hajar indicates that there was some dis-

18 "Sideways growth" is the phenomenon of relating from someone earlier what one had really learnt from a contemporary, remarked by Schacht but developed especially by Michael Cook, Early Muslim Dogma (Cambridge: Cambridge University Press, 1981), chap. 11.

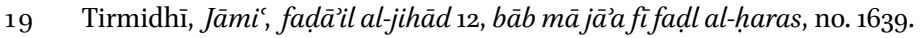

20 Tirmidhī, Tlal, 200-201, no. 356.

21 Al-Bukhārī, al-Tārīkh al-Kabīr, 4 vols in 8 (Hyderabad: Maṭba'at Dāirat al-Macāirif alNiẓāmiyya, 1941-1945, repr. with added index volume, Beirut: Dār al-Kutub al-'Tlmiyya,

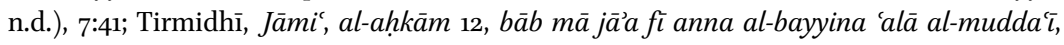
no. 1340 .

22 Tirmidhī, Jāmi', al-ḥudūd 22, bāa mā jăàa fì al-mar'a idhā ustukrihat 'alā al-zinā, no. 1453.

23 Bukhārī, Tārīkh, 6:106, 7:41. 
agreement over which brother did not hear directly from his father, apparently including al-Bukhārī when he was writing the entry for 'Alqama in al-Tärīkh alKabir and when he was answering al-Tirmidhi's question about him. ${ }^{24}$ Testing hadith by discrepant dates was evidently not only rare but highly uncertain.

\section{Mu'tazili Theory: Widely Recognized Hadith and Consensus}

The early Mu'tazila were interested in epistemology. We have reports in later sources of some of the positions they took. The earliest, Wāșil b. 'Ațā' (d. Basra, 131/748-749), is quoted as saying that there are just four ways of knowing the truth: by a clear passage of the Qurān, an undisputed report, a rational proof, and unanimous agreement. A report known by a single path of transmission was unverifiable, but there is not yet here a theory of tawätur. Dirār b. 'Amr (Kufan, fl. later 2nd/8th cent.) observed that different sects related contradictory hadith in support of their positions. He therefore upheld consensus instead of hadith. Abū Bakr al-Așamm (d. 20o/815-816?) rejected uncorroborated reports and likewise stressed consensus. Abū al-Hudhayl (d. Samarra, 226/840-841?) advocated a numerical test, such that a report could be considered authoritative if supported by twenty witnesses (a condition practically impossible to meet in reality). Al-Nazzāām (Basran, d. Baghdad, bef. 227/842), who collected contradictory hadith reports to show the extent of the problem, abandoned the distinction between corroborated and uncorroborated reports in favour of testing their content. ${ }^{25}$

One extant treatise by a ninth-century Mu'tazili is Kitāb al-Uthmāniyya by the littérateur al-Jāhị (d. 255/868-869). Although principally concerned

24 Ibn Hajar, Tahdhïb, 6:105, 7:28o. The Musnad of Ahmad b. Hanbal includes ten hadith reports with the link 'Alqama b. Wã'il $<$ his father, 13 hadith reports with the direct link 'Abd al-Jabbār b. Wā’il < his father but also five from 'Abd al-Jabbār b. Wā’il < his father with some intermediary, usually anonymous, in the middle.

25 Josef van Ess, "L'autorité de la tradition prophétique dans la théologie mu'tazilite," $L a$ notion d'autorité au Moyen Age, organized by George Makdisi, Dominique Sourdel and Janine Sourdel-Thomine (Paris: Presses Universitaires de France, 1982), 213-219. Cf. the summary of Racha el-Omari, "Accommodation and Resistance: Classical Mu'tazilites on Hadīth," Journal of Near Eastern Studies 71 (2012): 234-235. Dirār's collection of contradictory hadith has recently been published: Dirār b. 'Amr, Kitāb al-Tahrī̄sh, ed. Hüseyin Hansu and Mehmet Keskin (Istanbul: Sharikat Dār al-Irshād and Beirut: Dār Ibn Ḥazm, 1435/2014). For his advocacy of consensus, see for example his conclusion to a discussion of whom to pray behind: "You have disagreed over the reprobate, called one another liars, and refuted one another. What you have agreed on, that is the truth. In disagreement there is nullity and erring" (88). 
with theology, not law, it does discuss hadith. As summarized by A.H. Mathias Zahniser, it appears to follow al-Jāhịiz' master al-Nazzāam, at least inasmuch as it ultimately relies on consensus rather than hadith:

In summary, then, al-Jāhiziz' source criticism requires of transmitted data that it be widely recognized in diverse enough circles to preclude the possibility of fabrication. This historical method leads to the affirmation of the value of sira and maghāzi sources for use as evidence in serious theological discussion. It calls into question the elaborate system constructed by the Muhaddithūn for evaluating and verifying transmitted information, focusing on the two criteria of wide circulation among divergent groups and consensus among specialists rather than on considerations related to the quality of each link in the chain of transmitted data. ${ }^{26}$

Zahniser's evaluation has been challenged by Ignacio Sánchez, who argues that al-Jāhiz' distinction between general and specialized knowledge is close to and undoubtedly inspired by al-Shāfi'î's similar distinction. ${ }^{27}$ Although it seems to me that Sánchez is interestingly right to point out the interpretive power of consensus in both the Risāla of al-Shāfi' and the Uthmāniyya of al-Jāhịiz, ${ }^{28}$ I would also say that he unhelpfully runs together the distinction between 'ämm and khāsș in the purport of inspired texts and the 'ämma and khāsșa among interpreters (perhaps from being unaware of Norman Calder's work on each problem, never cited ${ }^{29}$ ), assumes without investigation that al-Jāhiz has taken his ideas from al-Shāfi'i as opposed to their both drawing on the conventional wisdom of their time (as notably suggested by Mohyddin Yahia, also not

26 A.H. Mathias Zahniser, "Source Criticism in the 'Uthmāniyya of al-Jāḥiẓ," Muslim World 70 (1980): 141 .

27 Ignacio Sánchez, "Shāfiī Hermeneutics and Qư’anic Interpretation in al-Jāḥiẓ’s Kitāb al'Uthmāniyya," in Tafsīr and Islamic Intellectual History, ed. Andreas Görke and Johanna Pink, Qur'anic Studies series 12 (London: Oxford University Press, 2014), 187-221.

28 Following Joseph E. Lowry's characterization of al-Shāfi'i’s view, "The Muslim community (in practice this means scholars) preserves a kind of communal record of what the Qurān and the Sunna mean and how they are interpreted": Early Islamic Legal Theory: The Risāla of Muhammad ibn Idrīs al-Shäfici, Studies in Islamic Law and Society 30 (Brill: Leiden, 2007), 327 .

29 Norman Calder, "Ikhtilâf and Ijmâc in Shâfi'î's Risâla," Studia Islamica 58 (1983): 55-81, on the distinction between rules that everyone knows and rules that only experts can know, and then only probably; idem, Studies in Early Muslim Jurisprudence (Oxford: Clarendon Press, 1993), 233-235, on general and particular meaning. 
cited $^{30}$ ), and never shows that al-Jāhiz, in the manner of al-Shāfi $\overline{1}$, endorses isnād comparison or other such measures to evaluate the reliability of individual hadith reports.

After al-Jāhiz, the earliest extant Mu'tazili account of hadith criticism is Qabūl al-Akhbār by Abū al-Qāsim al-Balkhī (d. Balkh, 319/931?), leader of the Baghdadi Mu'tazila in his time. Gautier H.A. Juynboll devoted a chapter to this book. Observing that most of it piles up shameful reports about Sunni traditionists of the past, Juynboll suggests that it scared the traditionists into reining in hadith criticism (that is, criticism of the men) lest it discredit all their hadith. ${ }^{31}$ The bulk of the book does look as though it is meant to discredit Sunni hadith generally. Famous traditionists are accused of changing the wording of hadith; for example, al-Naḍr 'Arabī, a client who lived in Harrān (d. 168/784), related hăfizū alà imānikum fì al-șalāt ("Watch over your faith in the ritual prayer"), but Jarīr, Wakī', and Mu'āwiya related it from him as hăa $i z \bar{u}$ 'alā abnäikum fí al-șalāt ("Watch over your sons in the ritual prayer"), meaning to command them to do it. ${ }^{32}$ Preposterous miracle stories are related; for example, that a woman seduced the wife of Abū Muslim al-Khawlānì (Syrian, d. $60 / 680$ or after?), so he cursed her and she went blind. She came to him, confessed, upon which he said, "O God, if she is telling the truth, return to her her sight," at which she saw again. ${ }^{33}$ Another section collects ridiculous sayings of traditionists; for example, Hishām b. 'Urwa (d. Baghdad, 146/763-764?) is quoted, "Whoever comes to Medina and brays ten times will not be harmed by its fevers." ${ }^{34} \mathrm{He}$ relates stories of disreputable behaviour by famous traditionists; for example, al-Sha' bì (Kufan, d.104/722-723?) played chess, putting a cloth over his head if someone came by who would recognize him, ${ }^{35}$ while Habīb b. Abī Thābit (Kufan, d. 119/737?) fell asleep, then prayed without first perform-

30 Mohyddin Yahia, Šäfī et les deux sources de la loi islamique (Turnhout: Brepols, 2009).

31 Gautier H.A. Juynboll, Muslim Tradition: Studies in Chronology, Provenance and Authorship of Early hadīth, Cambridge Studies in Islamic Civilization (Cambridge: Cambridge University Press, 1983), chap. 5. It is Abū al-Qāsim he has in mind when he says, "finally, after a Mu'tazilite rijāl critic's attempt to upset the applecart, the rijäl science settles down in a number of works to whose information no substantial or relevant additions are made" (163-164).

Abū al-Qāsim al-Balkhī, Qabūl al-akhbār wa-ma'rifat al-rijāl, ed. Abū 'Amr al-Husaynī b. 'Umar b. 'Abd al-Rahīm, 2 vols (Beirut: Dār al-Kutub al-'Ilmiyya, 1421/200o), 6o.

Abū al-Qāsim al-Balkhī, Qabūl, 158; Abū Dāwūd, al-Zuhd, with al-Marrūdhī, al-Warac, ed. Muṣṭafā Maḥmūd Ḥusayn (Tanta: Maktabat Dār al-Ḍiyā’ li-Taḥqīq al-Turāth, 1424/2003), 251-252, no. 499. Van Ess characterizes Abū al-Qāsim al-Balkhī as not attacking the contents of hadith, rather the characters of traditionists ("L'autorité," 222), but I disagree.

34 Abū al-Qāsim al-Balkhī, Qabūl, 150.

35 Abū al-Q̣̄sim al-Balkhī, Qabūl, 147. 
ing any ritual ablutions. ${ }^{36} \mathrm{Abu}$ al-Qāsim relates accusations of heterodoxy; for example Qatāda (Basran, d. 117/735-736?) was accused of qadar (rejecting predestination), ${ }^{37}$ 'Ațā' b. Abī Rabāh (Meccan client, d. 114/732-733?) was accused of being Murji', ${ }^{38}$ and Abū al-Sha'thā' (Jābir b. Zayd; Basran, d. 93/711-712?) frequented an Ibāḍi neighbour woman. ${ }^{39}$ And he tells stories of carelessness from traditionists; for example, al-A'mash (Sulaymān b. Mihrān; Kufan, d. 148/765?) prevailed on one Abū Mu'āwiya to relate to him hadith $<$ Hishām $<\mathrm{Sa}^{c} \overline{1} d<$ Mujāhid, then related it as directly < Mujāhid. ${ }^{40}$ Racha el-Omari stresses alBalkhi's introduction, defending the uncorroborated report in some circumstances; however, he allows consensus, practice ('amal), and reason (hujjat al'aql) to overrule a Prophet hadith report. ${ }^{41}$ This sounds fairly close to the line advocated by al-Jāhiiz and, at least as quoted, Wāṣil b. 'Ațā’ a century before him.

\section{$3 \quad$ Hanafi Theories of Hadith Criticism}

Ahmed El Shamsy has drawn attention to some brief comments on how to identify reliable hadith preserved near the beginning of Siyar al-Awzā $\bar{\imath}$, apparently a polemic by Abū Yūsuf (d. 182/798?) against the Syrian jurisprudent alAwzầi overlaid by polemics from al-Shāfíi ${ }^{42}$ Abū Yùsuf quotes advice from the Prophet through the Shi'i imam Muhammad al-Bāqir (d. 114/732-733?), "Hadith will spread from me (yafshī 'annī). What comes to you from me that agrees with the Qur'an, it is from me. What comes to you from me that disagrees with the Qur'ān, it is not from me."43 This is hadith criticism by content alone. More elaborately, Abū Yūsuf says himself,

\footnotetext{
36 Abū al-Qāsim al-Balkhī, Qabūl, 155.

37 Abū al-Q̄āsim al-Balkhī, Qabūl, 248.

38 Abū al-Qāsim al-Balkhī, Qabūl, 158.

39 Abū al-Qāsim al-Balkhī, Qabūl, 26o.

40 Abū al-Qāsim al-Balkhī, Qabūl, 271.

41 El-Omari, "Accommodation," 241. A little earlier, the sometime Mu'tazili Ibn al-Rāwandī (d. 298/910-911?) apparently published a book Ithbät khabar al-wāhid ("affirmation of the uncorroborated report"): Johann Fück, "Some Hitherto Unpublished Texts on the Mu'tazilite Movement from Ibn al-Nadīm's Kitāb-al-Fihrist," in Professor Muhammad Shafi` Presentation Volume, ed. S.M. Abdullah (Lahore: Majlis-e-Armughān-e-'Ilmī, 1955), 73.

42 Ahmed El Shamsy, The Canonization of Islamic Law (Cambridge: Cambridge University Press, 2013), 51 .

43 Al-Shāfììi, al-Umm, ed. Rif'at Fawzī 'Abd al-Muțțalib, 11 vols (al-Manșūra: Dār al-Wafā', 1422/2001; 2nd printing 1425/2004), 9:187. The closest I have found to this in a Shici collection is this from the next imam, Ja'far al-Ṣādiq (d. 148/765): "The Prophet gave an address from Minā, saying ..., 'O people, what comes to you from me that agrees with the Book of
} 
The evidence for what our party (al-qawm) has brought forth is that hadith from the Messenger of God ... and narration has increased in quantity. Some of what has transpired is unknown: it is unknown to qualified jurisprudents ( ahl al-figh) and disagrees with the Book and the sunna. Beware of aberrant (shädhdh) hadith. Incumbent on you is widelyaccepted hadith ( $m \bar{a}^{\prime}$ alayhi al-jamáa $\bar{a}^{\prime}$ ), what the jurisprudents recognize, and what agrees with the Qurān and sunna. Draw analogies from that. What disagrees with the Qur'àn is not from the Messenger of God ..., even if there is a narration of it. ${ }^{44}$

Again, the content test of agreement with the Quraan has the last word, but there is also some idea of majority acceptance to validate hadith.

According to Josef van Ess, Ḍiār b. 'Amr's rejection of hadith in favour of consensus continued outside Mu'tazilism with al-Shāfi î̀s opponent Ibrāhīm b. 'Ulayya (Basran, d. Old Cairo? 218/833) and the Hanafi Bishr al-Marīsī (d. Baghdad, 218/833-834). ${ }^{45}$ Al-Jașsāạ al-Rāzì (d. Nishapur, 37o/981) quotes extensively from the Hanafi qadi Īsā b. Abān (d. Basra? 221/836?) on the theory of hadith criticism. ${ }^{46}$ Murteza Bedir has devoted an article to these comments. I do not pretend to improve on Bedir's summary. He finds that 'Īsā b. Abān associates three levels of certainty with different sorts of reports. If the Companions disagreed about an issue, reports concerning it are uncertain. An uncorroborated report is to be rejected if it contradicts established sunna or the Qur'àn, if the public is ignorant of it, and if the people are not acting according to it. ${ }^{47}$ The kinship to Abū Yūsuf's and contemporary Mu'tazili ideas, stressing consensus, is clear. Isnād criticism has no place here.

God, I have said it. Whatever comes to you that disagrees with the Book of God, I did not say it'” —so al-Kulaynī, al-Käfì', ed. 'Alī Akbar al-Ghaffārī, corr. Muhammad al-Ākhundī, 8 vols (Tehran: Dār al-Kutub al-Islāmiyya, 1389, 1391), 1:69.

44 Shāfi ī Umm, 9:188-189. Cited in support of caution regarding hadith-based law today by Fazlur Rahman, Islamic Methodology in History, Central Institute of Islamic Research (Pakistan) 2 (Karachi: Central Institute of Islamic Research, 1965), 35 .

45 Van Ess, "Autorité," 216. Ahmed El Shamsy's recent demonstration that al-Shāfi'î's short work Jimāa al-Tlm is directed partly against Ibrāhīm b. 'Ulayya complements Joseph Lowry's observation that it is directed against someone who adduces $i j m \bar{a}^{c}$ when he is actually relying on an uncorroborated report: El Shamsy, Canonization, 55-57; Lowry, Early Islamic, 323 .

46 Al-Jașșāṣ al-Rāzī, al-Fuṣūl fi al-Ușūl, ed. 'Ujayl Jāsim al-Nashmī, al-Turāth al-Islāmī 14, 4 vols (2nd printing, Kuwait: Wizārat al-Awqāf wa-al-Shu’ūn al-Islāmiyya, 1414/1994).

47 Murteza Bedir, "An Early Response to Shāfīì: ‘̄sā b. Abān on the Prophetic Report (khabar)," Islamic Law and Society 9 (2002): 300-305. Cf. Aron Zysow, The Economy of Certainty, Resources in Arabic and Islamic Studies (Atlanta: Lockwood, 2013), 17-19, likewise review- 
Bedir makes out that 'Īsā is arguing specifically against al-Shāfi 'ì, but I doubt it. Al-Jaș̣āas himself once states that he is quoting İ̃ā b. Abān from his book refuting Bishr al-Marīsī. ${ }^{48}$ Bedir says, "Īsā wrote against al-Shāfi'̄i, a point on which the sources are unanimous." ${ }^{49} \mathrm{He}$ cites just two sources, though, Ibn alNadīm and Wakī‘ The earlier, Wakī` (d. Baghdad, 306/918), says this:

'Īsā b. Abān had little writing from Muhammad b. al-Ḥasan (kāna qalīl alkitāb 'an Muhammad b. al-Hasan). No one has informed me that he saw him with Abū Yūsuf. I have been told that the hadith reports he turned against al-Shāfi'ì (al-ahāādìth allatī raddahà 'alā al-Shāficì) he took from the book of Sufyān b. Saḥbān. ${ }^{50}$

("Sufyān b. Saḥbān" should be corrected to Sakhtān, a Kufan disciple to Ḍirār b. 'Amr. ${ }^{51}$ ) Ibn al-Nadīm (d. Baghdad, 38o/99o?) offers a shorter version of the same:

It is said that he learnt little from Muhammad b. al-Hasan. It is also said that he did not attend (sessions with) Abū Yūsuf. The hadith reports he turned against al-Shāfīi he took from the book of Sufyān b. Saḥbān. ${ }^{2}$

Additionally, I have come across this reference from al-Khațīb al-Baghdādī, quoting the response of Dāwūd al-Ẓāhirī (d. Baghdad, 270/884) to a suggestion that he refute attacks on al-Shāfi'i from 'Īsā b. Abān and Ibrāhīm b. 'Ulayya:

As for 'Īsā b. Abān, I do not regard him as one of the people of knowledge. His book is nothing. It is meaningless - boys can refute it. It is just

ing 'Īsā b. Abān's definitions as reported by al-Jașșāṣ but developing mainly the intraHanafi controversy over the mashhür report-whether to consider it a sub-category of the mutawātir.

48 Jașsāṣ, Fuṣull, 3:35.

49 Bedir, "Early Response," 291.

50 Wakī', Akhbār al-Quḍāt, ed. 'Abd al-'Azīz Mușțafā al-Marāghī, 3 vols (Cairo: Maṭba'at alIstiqāma, 1366-1369/1947-1950), 2:171.

51 As to the name, see Ibn Ḥajar, Tabșìr al-Muntabih bi-Tahrīr al-Mushtabih, ed. 'Alī Muhammad al-Bijāwī, rev. Muḥammad 'Alī al-Najjār, Turāthunā, 4 vols (Cairo: al-Dār al-Miṣriyya lil-Ta'līf wa-al-Tarjama, 1964?-1967, repr. Beirut: al-Maktaba al-'Tlmiyya, n.d.), 2:676. For what little is known of the man, see Josef van Ess, Theologie und Gesellschaft im 2. und 3. Jahrhundert Hidschra, 6 vols (Berlin: Walter de Gruyter, 1991-1995), 3:6o-61.

$5^{2}$ Ibn al-Nadìm, Kitâb al-Fihrist, ed. Gustav Flügel, with Johannes Roedigger and August Mueller (Leipzig: F.C.W. Vogel, 1872), 205 ( fann 2, maqāla 6). 
something that Ibn Sakhtān helped him with. But I have written a refutation of Ibrāhīm b. Ismāîil b. 'Ulayya's book, which I am about to finish. ${ }^{53}$

It seems indisputable, then, that '̄sā wrote something against al-Shāfi'ì. However, if Bishr al-Marīsī professed to construct Islamic law without resort to hadith, that would be reason enough for 'Īsā b. Abān to argue against him (i.e. not against al-Shāfici) that reports are of variable reliability, some compelling belief. Similarity to Abū Yūsuf's position and lack of discussion of the special problem of authenticating uncorroborated reports additionally suggest that the work quoted by al-Jașșāṣ is not specifically ‘īsā b. Abān's refutation of al-Shāfi'ì. A separate lost refutation of al-Shāfi'i over particular rules would account for the notices from Waki ${ }^{`}$ and Ibn al-Nadìm, both referring to hadith he used, not the theory of uncorroborated reports.

Al-Ṭahāwī (d. Old Cairo, 321/933) is a Hanafi who wrote extensively on hadith. His large works Sharh Ma'ānī al-Äthār and Sharh Mushkil al-Āthār deal with apparently contradictory hadith mainly by harmonization, not hadith criticism. Like al-Shāfi ī and al-Muzanī (d. Old Cairo, 264/877?), he was a "hadith commentator," not a "hadith critic." 54 However, as he describes his method in the introduction to Sharh al-Ma'anni, he recalls Mu'tazili theory rather than that of al-Shāfīi or Muslim:

I shall mention in each book what concerns it by way of the abrogating and the abrogated, the interpretation $\left(t a^{\prime} w \bar{l} l\right)$ of the 'ulam $\bar{a}^{3}$, and the arguments of one against another. (I shall mention) whose position I regard as sound on account of what is shown to be sound by something similar by way of a passage of the Book, a precedent of the Prophet (al-sunna), consensus, or what is widely circulated (tawätara) by way of the positions of the Companions and Followers. ${ }^{55}$

This is to stress the wisdom of the community, giving no space to uncorroborated reports accepted because of the demonstrated reliability of the men in their asānid. In the introduction to Sharh al-Mushkil, he suggests that only misunderstanding hadith reports makes it appear that they are contradictory. ${ }^{56}$

53 Al-Khațīb al-Baghdādī, Tārīkh Madīnat al-Salām, ed. Bashshār 'Awwād Ma'rūf, 17 vols (Beirut: Dār al-Gharb al-Islāmī, 1422/2001), 6:513-514; earlier cited by Van Ess, Theologie, 3:6ofn.

54 Dickinson, Development, 5-7.

55 Al-Ṭahāwī, Sharh Ma ān̄̄ al-Āthārr, ed. Muḥammad Sayyid Jād al-Ḥaqq, 4 vols (Cairo: Mațbacat al-Anwār al-Muhammadiyya, n.d.), 1:11.

56 Al-Ṭahāwī, Sharḥ Mushkil al-Āthār, ed. Shu'ayb al-Arna'ūt, 16 vols. (Beirut: Mu’assasat al- 
In practice, unsurprisingly, al-Ṭahāāī is more opportunistic and eclectic. For example, he will cite an earlier authority aspersing someone in the isnād of a hadith report that contravenes the Hanafi position, dismiss a rule observed only in one region, recommend a hadith report as being related by both Meccans and Kufans, or prefer the version endorsed by two famous eighth-century traditionists (Sufyān al-Thawrī and Mālik b. Anas) against another version endorsed by only one (Sufyān b. 'Uyayna). ${ }^{57} \mathrm{He}$ apparently resorts to dogma to refute a hadith report from 'A'isha (supporting the Shafi'i position) over the number of sucklings that create a marriage bar:

Among what was sent down of the Quran was "ten known sucklings render forbidden," which was abrogated by "five known." The Messenger of God ... died as they were among what was recited of the Qur'ān. ${ }^{58}$

Al-Ṭahāwī says that this must have been a fantasy of one of its transmitters, 'Abd Allāh b. Abī Bakr (Medinese, d. 135/752-753), since otherwise it would be permissible to recite this verse in the ritual prayer. Besides, none of the imams (leading jurisprudents) related this hadith report except Mālik b. Anas, who went against it. ${ }^{59}$ It does appear in the Muwatta' of Mālik with the comment "Practice is not according to this," but it is also in the Umm of al-Shāfi'ì (overlooked by al-Ṭaḥāwī?), supporting the Shafíi rule. ${ }^{60}$ At most,

Risāla, 1415/1994), 1:5-6. Similarly, Carolyn Anne Brunelle, "From Text to Law: Islamic Legal Theory and the Practical Hermeneutics of Abū Jacfar Aḥmad al-Ṭahāwī (d. 321/933)" (Ph.D. diss., University of Pennsylvania, 2016), 66-67.

57 For a review of his hadith criticism, see 'Abd al-Majīd Maḥmūd, Abū Ja'far al-Tahāāwè wa-Atharuhu fi al-Hadīth, al-Maktaba al-'Arabiyya (Cairo: al-Hay'a al-'̄̄mma lil-Kitāb, 1395/1975), 197-240.

58 Here quoted from Muslim, al-Jāmic al-Ṣaḥ̄h, al-raḍā̄ 6, bāb al-tahrīm bi-khams radacāt, no. $145^{2}$.

59 Maḥmūd, Abū Jacfar al-Tahāōwī, citing al-Ṭahāwī, Mushkil al-Āthār, ed. Ibrāhīm b. 'Abbās b. Ibrāhīm al-Raḍawī (Hyderabad: Maṭba'at Majlis Dāirat al-Ma'āif al-Niẓāmiyya, 1333), 3:6-8. Versions also appear in al-Dārimī, al-Sunan, al-nikāḥ 49, bāb kam raḍ'atan tuharrim, and Abū Dāwūd, Sunan, al-nikāh 1o, bāb hal yuharrimu mā dūna khams raḍăàt, no. 2062, among other places. On the juridical controversy, see John Burton, The Sources of Islamic Law: Islamic Theories of Abrogation (Edinburgh: Edinburgh University Press, 199o), 156164.

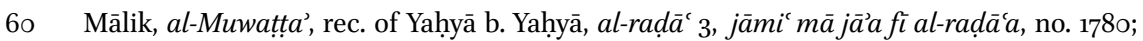
Shāfīīi, Umm, 6:72. Besides Muslim (one version through Mālik, two Medinese parallels), see Abū Dāwūd, Sunan, al-nikāh 10, bāb hal yuharrimu mā dūna khams raḍáāt? no. 2062 (through Mālik); Nasā̄ì, Mujtabā, al-nikāh 51, al-qadr alladhīyuharrimu al-raḍ̄áa, no. 3309 (through Mālik); Ibn Māja, Sunan, al-nikāḥ 35, bāb lā tuḥarrimu al-mașșa wa-lā al-mașșatān, no. 1942 (Basran/Medinese isnād). 
then, it fits under the heading of a position of the Companions and Followers not widely circulated; but al-Ṭahāwī hardly excludes such hadith consistently.

I have alleged before that al-Shāfíi did not himself practise hadith criticism. Rather, he periodically invokes the opinions of unnamed experts when he wants to reinforce or diminish the authority of a hadith report as it supports or contravenes his position. ${ }^{61}$ This is not an invariable rule, but when he departs from it to discredit some hadith report going against his proposed rule, he sounds as opportunistic as al-Ṭahāīī a century later. For example, he quotes two hadith reports in favour of raising the hands repeatedly during the ritual prayer, not only at the opening, then says, "We have left, concerning these hadith reports, whatever hadith contradicts them, for they have more reliable asānìd, being numerous. What is numerous is more worthy of being preserved than what is just one." ${ }^{22}$ He goes on to anecdotal evidence from Sufyān b. 'Uyayna that the Medinese authority Yazīd b. Abī Ziyād related a hadith report about raising the hands one way in Medina, with a crucial addition in Kufa. ${ }^{63}$ Indeed, it seems likely that traditionists felt pressure to produce hadith supporting local ways. What seems unlikely to the modern critic is that this happened only in Kufa, not other centres as well.

Refutations of rival jurisprudents, hence a sort of hadith criticism, are considerably more common in the short works (what Joseph Schacht called the treatises) than the Umm itself. In Ikhtilāf Mãlik wa-al-Shāfici, al-Shāfíi usually argues that someone (not always Mālik) has set aside the word of the Prophet in favour of more recent authorities. In the following passage, he accuses his Māliki interlocutor of caprice in accepting or rejecting uncorroborated hadith:

61 Christopher Melchert, "Traditionist-Jurisprudents and the Framing of Islamic Law," Islamic Law and Society 8 (2001): 393-394.

62 Shāfi '̄i, Umm, 2:234-235. Joseph Lowry has pointed out some similar uses of consensus in the Risāla, preferring a hadith report transmitted by many to one transmitted by isolated individuals: Early Islamic, 339 .

63 Shāfi ī, Umm, 2:236. A similar argument in Ikhtilāf Mālik wa-al-Shāfì̄, Umm, 8:541-545, where those who prefer the hadith report with only one raising of the hands is opposed to over ten versions (not enumerated) to the contrary. 
I said to al-Shāfi'î, "It has been related to us that Rabīa [Mālik's teacher Rabī'at al-Ra'y (d. 136/753-754?)] said, 'It has been a long time and there has occurred much change in hadith.' I fear there is some mistake in the narration."

Al-Shāfi'i said, "I don't know anyone who has argued by a weaker argument than yours, nor have you ever argued by anything weaker than this."

I said, "How so?"

He said, "Haven't you seen that what we have learnt of the Prophet ... and those after him of his Companions is by the report of one from one? You cast suspicion on what has been related from the Prophet ... because it is possible for one to be mistaken (in relating hadith) from one."

I said, "Perhaps Ibn Shihāb was mistaken concerning (what he had heard from) Abū Salama, or Abū Salama mistaken concerning (what he had heard from) Jābir ..."

I said, "So how is it that you have once pronounced reliable what may be mistaken and another time rejected it? Is it right to do anything but pronounce it all reliable on account of the apparent truthfulness of the ones relating it, as you pronounce reliable (someone's) testimony? What is pronounced reliable from the Prophet ... is more worthy $(a w l \bar{a})$ of our acceptance than what is pronounced reliable from anyone else. Otherwise, we should have to reject it all, if there is a possibility of a mistake concerning it, as they reject it who reject uncorroborated reports ( $a k h b \bar{a} r$ $a l-k h \overline{a s s s a}$ ). You have not done either of these things, rather put yourself in a position to reject what you like and accept what you like, on no principle I know you to recognize." ${ }^{\prime 4}$

(Al-Shāfi'ìs interlocutor should be his disciple al-Rabī' b. Sulaymān al-Murādī, but qultu in this passage is deployed inconsistently, so it may have been built up of fragments of something earlier against someone else.) In the background

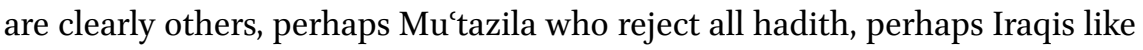
Abū Yūsuf who reject hadith not widely known, which al-Shāfici insists on considering probative. But he resorts to no systematic method of sorting probably from improbably accurate transmission. Rather, in effect, he asserts that we do know what the Prophet said just because we must know what the Prophet said.

64 Shāfīi $U m m, 8: 75$ o. El Shamsy quotes the next section of this passage, in which al-Shāfi ì refers to "those who abolish prophetic reports in their entirety, saying, 'We adhere to consensus'”: El Shamsy, Canonization, 67. El Shamsy identifies this as the approach of Ibrāhīm b. 'Ulayya. 
Al-Shāfi'ì's refutation of al-Shaybānī, al-Radd 'alā Muhammad b. al-Hasan, begins with a dispute over the size of the wergild (diya). Typically, al-Shāfi'i quotes Hijazi hadith against the Kufan hadith that al-Shaybānī has quoted without actually showing where the Kufan tradition is in error. The next section treats the question of whether a free murderer should be put to death for killing a slave. Al-Shāfi' ì says there is no probative hadith report on the matter but that logical consistency with other parts of the law requires a different penalty for killing a slave. After that comes the comparative wergild for body parts of men and women, where al-Shāfi'i insists that when the Follower Saì b. al-Musayyab adduces the sunna, it must indicate that the proposed rule goes back to the Prophet. ${ }^{65}$ And so it goes-almost nowhere, so far as I have noticed, does he bother with proper isnād criticism. (El Shamsy cites one example of complaining that his opponent, probably al-Shaybānī, relies on a hadith report with an incomplete isnād. ${ }^{66}$ ) Often, the law has to have some other basis than Qurān and Prophet hadith - the two examples just given, of positions supported only by logical consistency or a Follower report, are by no means rare.

When it comes to relying on Qur'ān and hadith, the extreme end of the Sunni spectrum is of course occupied by Ahmad b. Hanbal and the traditionalists around him. If pressed, he would defend his position as based on hadith. In cases of contradictory hadith, he would sometimes present the material and leave it to the one asking to choose a position. ${ }^{67}$ As for consensus, he doubted whether it was a reliable means by which to know the law:

Whatever a man asserts that there is consensus over, it is a lie. Whoever claims consensus is a liar. Perhaps the people disagreed. This is the position of Bishr al-Marīsī and al-Așamm. Rather, one should say, "It is not known that the people disagreed" or that he has not heard of that. ${ }^{68}$

65 Shāfi 'ī, Umm, 9:85-94. Schacht's guess that al-Radd 'alä Muhammad b. al-Hasan commented on a part of Shaybānī's K. al-Ḥujaj is shared by the editors of al-Shaybānī, K. al-Hujja 'alā Ahl al-Madīna, ed. Abū al-Wafă’ al-Afghānī et al., Silsilat al-Mațbūâat 1, 4 vols. (Hyderabad: Mațba'at al-Macārif al-Sharqiyya, 1385/1965, repr. Beirut: 'Ālam al-Kutub, 1403/1983), which see at 4:255-418. Cf. Joseph Schacht, The Origins of Muhammadan Jurisprudence (Oxford: Clarendon Press, 1950), 338.

66 El Shamsy, Canonization, $51 \mathrm{fn}$. For other discussions of the report in question, sceptical but less emphatic than al-Shāfíī, see inter alia Bukhārī, al-Tārīkh al-Kabīr, 2:25-26, s.n. Ayman al-Habashī, and Ibn Ḥajar, Tahdhīb, 1:394-395, s.n. Ayman mawlā al-Zubayr.

67 See Susan A. Spectorsky, "Ahmad Ibn Hanbal's Fiqh," Journal of the American Oriental Society 102 (1982): 461-465; Christopher Melchert, Ahmad ibn Hanbal, Makers of the Muslim World (Oxford: Oneworld, 2006), chap. 3 .

68 'Abd Allāh b. Aḥmad, Masā̉il al-imām Aḥmad b. Hanbal, ed. Zuhayr al-Shāwīsh (Beirut: 
But this is evidently against those who would substitute consensus for hadith. Although reluctant to declare something forbidden that he did not know the Prophet to have forbidden, Ahmad himself could also be quoted as accepting a practice on the ground that it was established practice (al-'amal 'alayh), not merely that the hadith supporting it was the best available evidence. ${ }^{69}$ And he would sometimes appeal to consensus himself; for example, that one should not insert the basmala before Q. 9, rather "One stops, as to the Qurān, at what Muhammad's Companions agreed upon (mā ajma'ū 'alayhi aṣhāb Muhammad), nothing to be added to it or subtracted."70

From the middle of the century we have a treatise from the influential Hanafi al-Khașșāf (d. 261/874), Kitāb Ahkām al-Waqf on the rules of charitable foundations. Al-Khașsāaf had the reputation of fitting hadith to Hanafi opinion, and this book begins with a chapter comprising relevant hadith, mostly going back to the Prophet and mostly with asānìd. However, the asānìd are often manifestly incomplete; e.g. < Mufaḍḍal b. Faḍāla (Egyptian, d. 181/797?) < Yazīd b. Abī Ḥabīb (Egyptian client, d. 128/745-746) < the Prophet. ${ }^{71}$ Moreover, al-Khașșāf almost never cites hadith in subsequent chapters, preferring to elaborate the law by appeal to consistency or, less often, the opinions of Abū Ḥanīfa, Abū Yūsuf, and al-Shaybānī.

\section{$5 \quad$ To the Present}

It may be said that the early Mu'tazili approach has enjoyed renewed popularity among Muslim liberals who find congenial values in the Qurān and dismiss contrary hadith as merely preserving the patriarchal attitudes (among other things) of eighth- and ninth-century Muslim men. For example, I have complained of Azizah al-Hibri's assertion that "traditionally, a hadith which appears to contradict a Qur'ānic passage is usually viewed as based on a false

al-Maktab al-Islāmī, 1401/1981), 438-439. Also cited by El Shamsy to support a different point, but he prefers a version from Ibn Taymiyya by which Ahmad named not al-Așamm but Ibrāhīm b. 'Ulayya: Canonization, 56 .

69 Jonathan A.C. Brown, "Did the Prophet Say It or Not? The Literal, Historical, and Effective Truth of Hadiths in Early Sunnism," Journal of the American Oriental Society 129 (2009): 277, citing an 11th-century Hanbali work which, however, apparently draws in turn on a 9th-century collection of Ahmad's teaching.

70 Șāliḥ b. Aḥmad, Masāil al-imām Ahmad b. Hanbal, ed. Ṭāriq b. 'Awaḍ (sic) Allāh b. Muḥammad (Riyadh: Dār al-Wațan, 1420/1999), 55, no. 168.

71 Al-Khașsāâ, K. Aḥkām al-Awqā̃f (n.p.: Maṭba'at Dīwān 'Umūm al-Awqāf al-Mișriyya, 1322/ 1904), 3 . 
report or is reinterpreted in a fashion consistent with the Qur'an."72 This is preposterous as a description of the Sunni tradition, in which the Qurānic passage would be reinterpreted (probably by restriction of its application) so as not to contradict the hadith report. However, it apparently agrees with the priority Wāșil b. 'Ațā' accorded clear passages of the Qur'ān. Implicitly ("usually viewed"), it also appeals to consensus.

Fatima Mernissi recounts being driven to perform her own hadith criticism after being reduced to silence by someone's citation of the report, "Those who entrust their affairs to a woman will never know prosperity." First of all, she looks into the biography of the Companion who transmitted it. Mālik calls for every hadith transmitter to be truthful even outside the transmission of hadith. "If we apply this rule to Abu Bakra," says Mernissi, "he would have to be immediately eliminated, since one of the biographies of him tells us that he was convicted of and flogged for false testimony by the caliph 'Umar b. alKhattab." (He was one of four who accused someone of adultery. When one of them withdrew his testimony, the rest were flogged for qadhf.) Moreover, she goes on, "Even though it was collected as sahih (authentic) by al-Bukhari and others, that hadith was hotly contested and debated by many. The scholars did not agree on the weight to give that hadith on women and politics. ${ }^{73}$ In agreement with early Mu'tazili theory, then, Mernissi questions a hadith transmitter's qualification to give testimony (hence also to be relied on to transmit hadith correctly), then complains that the proposed rule is outside consensus, besides.

By contrast, isnād comparison still has its followers among modern Salafiyya. For example, here is some recent online hadith criticism concerning the hadith report, "There is no mahdī except 'Isā":

One of its narrators is Muhammad b. Khalid al-Jundi.

72 Azizah al-Hibri, "Islam, Law and Custom: Redefining Muslim Women's Rights," American University Journal of International Law and Policy 12 (1997): 5. Cf. Christopher Melchert, "Whether to Keep Women Out of the Mosque," Authority, Privacy and Public Order in Islam, ed. B. Michalak-Pikulska and A. Pikulski, Orientalia Lovaniensia analecta 148 (Leuven: Peeters, 2006), 59 .

73 Fatima Mernissi, The Veil and the Male Elite, trans. Mary Jo Lakeland (Boston: Addison-

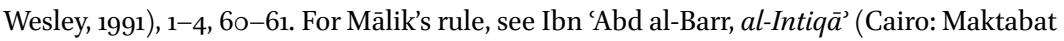
al-Qudsī, 1350), 15-16. For the hadith report in question, see Bukhārī, Șaḥịh, al-maghāzī 83, bāb kitāb al-nabì ilā Kisrā wa-Qayșar, no. 4425, and al-fitan 18, no. 7099. For the story of Abū Bakra, see al-Ṭabarī, The History of al-Tabarī 13: The Conquest of Iraq, Southwestern Persia, and Egypt, trans. Gautier H.A. Juynboll, Bibliotheca Persica and sunY Series in Near Eastern Studies (Albany: State University of New York Press, 1989), 110-114 (s.a. 17). 
Firstly Hafiz Ibn Hajar, after careful scrutiny of the various opinions, graded him as "Majhul" i.e. unknown. See al-Taqrib 2/71.

Imam Hakim also classified him as "Majhul" see Tahzib al-Tahzib 9/126

In fact the narration has multiple issues. Shaykh Albani (in Silsala Da'ifa-weak chain-, Number 77) has mentioned three problems in this.

1. Tadlis of Hassan al-Basri

2. Muhammad bin Khalid al-Jundi being Majhul.

3. Difference in the chain. At another place Muhammad bin Khalid narrates from Aban bin Abi Ayyash instead of Aban bin Salih and he is "Matrook" i.e. rejected. See Tahzib al-Tahzib 9/126

It is for this reason; Imam Ibn Taymiya, al-Saghani, al-Shaukani, Ibn Qayyim, al-Dhahbi, al-Qurtubi, Azimabadi etc. and recently Albani and Shu'aib Arnaut all have graded this narration as dubious. ${ }^{74}$

The third quoted objection from Muhammad Nāșir al-Dīn al-Albānī has to do with isnād comparison, showing that a given report was supported by contradictory asānid (the technical term is mudtarib). However, the heavy stress on authorities (Ibn Ḥajar, al-Ḥākim al-Naysābūrī, al-Albānī himself et al.) also betrays a certain tendency to rely on consensus after all, just as the Mu'tazila called for.

We should also think of similarities between our approach today and that of medieval Muslim scholars. As personal character turns out not to have played a crucial role in medieval Islamic hadith criticism, so personal character plays virtually no part in our debates. For example, it is conventional if I complain (rightly or wrongly), "Bedir stresses 'Īsā's opposition to al-Shāfi'ì, but the connection is poorly demonstrated." It would be strange for me to add (rightly or wrongly), "Moreover, Bedir continually shirks administrative assignments." It is also fairly conventional among modern scholars to appeal to consensus, as when Etan Kohlberg says of hadith (rightly or wrongly), "there appears to be a large measure of scholarly agreement to the effect that traditions were being accurately recorded and transmitted in the early 2nd/8th century."75

74 From http://islamic-forum.net/index.php?showtopic=19246, accessed 15 June 2013. For the hadith report in question, see Ibn Māja, Sunan, al-fitan 24, bāb shiddat al-zamān, no. 4039 .

75 Etan Kohlberg, "Introduction [to the section on hadith]," in The Study of Shici Islam: History, Theology and Law, eds Farhad Daftary and Gurdofarid Miskinzoda, The Institute of Ismaili Studies Shi'i Heritage series 2 (London: I.B. Tauris, 2014), 175. The accompanying note makes clear that he has in mind the early fixing of the law, both Sunni and Shi' $\mathrm{i}$, not merely early creation of written notes. 
At the level of theory, it appears that the method described by al-Shāfi ì , intended to demonstrate the value of the uncorroborated report, was the way of the future. The method of al-Bukhārī and Muslim was similar, with a little more emphasis on isnād comparison and less on the personal probity of the men in asānìd, regarding which they had to be acutely aware that they usually suffered from a dearth of information. They still preferred to pile up parallel versions where possible to demonstrate corroboration. The contemporary Mu'tazili approach, by contrast, tended to downplay hadith, especially uncorroborated, in favour of consensus and communal practice. Hanafi theory seems to have been similar.

On the other hand, if in theory the Sunni approach stressed sound hadith, in practice (at least away from the extreme traditionalist end represented by Ahmad b. Hanbal), it continually rested instead on consensus. For example, after presenting a hadith report with the dubious link 'Abd al-Jabbār b. Wāil from his father (as discussed above), al-Tirmidhī says, "This one is uncorroborated (gharīb), with a discontinuous isnād." He quotes al-Bukhārī, as noted, declaring that 'Abd al-Jabbār never met his father. But then al-Tirmidhī concludes, "Practice goes by this hadith report in the view of the people of knowledge of the Companions of the Prophet ... and others: that there is no hadd punishment for the woman who is forced."76 I have noted before the similar examples of the yield and the guaranty (above) and judicial procedure (in a previous article): al-Tirmidhi finds fault with the hadith report that supports his rule but then concludes, "Practice goes by this hadith report in the view of the people of knowledge of the Companions of the Prophet ... and others: that proof is incumbent on the claimant and the oath on the accused." ${ }^{77}$ Usually, this expression follows a hadith report that al-Tirmidhī has dubbed "good and sound"; sometimes, after another "good and sound" hadith report, he states only, "Practice goes by this hadith report in the view of most of the people of knowledge" or even "some of the people of knowledge." But "practice goes by this hadith report according to all the people of knowledge" follows more than a dozen additional hadith reports admittedly gharīb (uncor-

76 Tirmidhī, Jāmi', al-ḥudūd 22, bāb mā jāàa fi al-mar'a idhā ustukrihat 'alā al-zinā, no. 1453.

77 Tirmidhī, Jāmi', al-ahkām 12, bāb mā jā̉a fî anna al-bayyina 'alā al-mudda'̄ wa-al-yamìn 'alā al-mudda'ā 'alayh, nos. 1340-1342. Christopher Melchert, "The History of the Judicial Oath in Islamic Law," Oralité et lien social au Moyen Âge (Occident, Byzance, Islam), eds Marie-France Auzépy and Guillaume Saint-Guillain, Centre de recherche d'histoire et civilisation de Byzance Monographies 29 (Paris: ACHCByz, 2008), 325 . 
roborated) or outright unsound. Al-Tirmidhī lets consensus make up for a weak basis in hadith. This seems to have become the prevailing Sunni position.

There is a certain tradition in modern scholarship of finding that consensus $\left(\ddot{j} m \bar{a}^{c}\right)$ is the ultimate authority in Islamic law. An older generation of Anglophone Islamicists must all have read this, for example:

Indeed, on a strict logical basis, it is obvious that $\ddot{j} m \bar{a}^{c}$ underlies the whole imposing structure and alone gives it final validity. For it is $i j m \bar{a}^{c}$ in the first place which guarantees the authenticity of the text of the Koran and of the Traditions. It is $i j m \bar{a}^{c}$ which determines how the words of their texts are to be pronounced and what they mean and in what direction they are to be applied. ${ }^{78}$

At the level of jurisprudence that concerns him, Aron Zysow is right to say, "the usual presentation of $\ddot{j} m \bar{a}^{c}$ as the cornerstone of Islamic legal theory is misleading ... It is tawātur that provides Islamic law with its historical basis, the existence and actions of the Prophet, the authenticity of the Quraan in its various readings. ${ }^{79}$ In works expounding actual rules, however, it appears that consensus is the ultimate arbiter after all. It is testimony to its persistence in non-Mu'tazili, Sunni texts that modernists such as al-Hibri and Mernissi should assume that their appeals to consensus and specifically qualification to testify are traditional (it is hardly to be imagined that they were consciously arguing along Mu'tazili lines). ${ }^{80}$ This is not the theorized consensus of classical jurisprudence (especially as expounded in the eleventh century and later-alShāfi'ìs own defence of $\ddot{j} m \bar{a}^{c}$ is notably sketchy $\left.{ }^{81}\right)$ but something more intuitive. Perhaps it is comparable to the Roman Catholic formula of quod semper,

78 Hamilton A.R. Gibb, Muhammedanism, 2nd edition (Oxford: Oxford University Press, 1962), 96 .

79 Zysow, Economy of Certainty, 155 .

80 On the revival of Mu'tazilism in the modern period, see for example Richard C. Martin and Mark R. Woodward with Dwi S. Atmaja, Defenders of Reason in Islam: Mu'tazilism from Medieval School to Modern Symbol (Oxford: Oneworld, 1997), and Thomas Hildebrandt, Neo-Mu'tazilismus? Intention und Kontext in modernen arabischen Umgang mit dem rationalistischen Erbe des Islam, Islamic Philosophy, Theology, and Science, Texts and Studies 77 (Leiden: Brill, 2007). Both say much of theology and rationalism, little or nothing of hadith and consensus.

81 "It is also possible that Shäfi'i's concept of $\ddot{j} m \bar{a}^{\iota}$ is simply extremely informal and that the focus on it in the secondary literature (which has driven this chapter) has led to an overestimation of its significance": so the exasperated conclusion of Lowry, Early Islamic, $35^{6-357 .}$ 
quod ab omnibus credituni est ("what has been believed everywhere, always, and by all") cited to justify what might appear to be new.

\section{Bibliography}

'Abd Allāh b. Aḥmad. Masā̄il al-imām Aḥmad b. Hanbal. Edited by Zuhayr al-Shāwīsh. Beirut: al-Maktab al Islāmī, 1401/1981.

Abu-Alabbas, Belal. "The Principles of Hadith Criticism in the Writings of al-Shāfíi and Muslim." Islamic Law and Society 24 (2017): 311-335.

Abū al-Qāsim al-Balkhī. Qabūl al-akhbār wa-ma'rifat al-rijāl. Edited by Abū 'Amr alHusaynīb. 'Umar b. 'Abd al-Raḥīm. 2 vols. Beirut: Dār al-Kutub al-'Ilmiyya, 1421/20oo. Abū Dāwūd. Al-Sunan. Numerous editions. Individual reports conventionally numbered after edition of Muḥammad Muḥyī al-Dīn 'Abd al-Ḥamīd. 4 vols. Cairo: Mațba'at Muṣțafā Muḥammad, 1354.

Abū Dāwūd. Al-Zuhd. With al-Marrūdhī, al-Wara . Edited by Muștafā Maḥmūd Ḥusayn. Tanta: Maktabat Dār al-Ḍiyā' li-Taḥīq al-Turāth, 1424/2003.

Aḥmad b. Hanbal. Kitāb al-Tlalwa-Márifat al-Rijāl. Edited by Waṣī Allāh b. Muḥammad 'Abbās. 4 vols. Beirut: al-Maktab al-Islāmī, 1988. = Edited by Mụammad Ḥusām Bayḍūn. 2 vols. Beirut: Mu’assasat al-Kutub al-Thaqāfiyya, 1410/199o.

Bedir, Murteza. "An Early Response to Shāfi'î: 'Īsā b. Abān on the Prophetic Report (khabar)." Islamic Law and Society 9 (2002): 285-311.

Brown, Jonathan A.C. "Did the Prophet Say It or Not? The Literal, Historical, and Effective Truth of Hadiths in Early Sunnism." Journal of the American Oriental Society 129 (2009): 259-285.

Brunelle, Carolyn Anne. "From Text to Law: Islamic Legal Theory and the Practical Hermeneutics of Abū Ja'far Aḥmad al-Ṭahāwī (d. 321/933).” Ph.D. diss., University of Pennsylvania, 2016.

Al-Bukhārī. Al-Tārīkh al-Kabīr. 8 vols. Hyderabad: Maṭba'at Dāirat al-Ma‘̄āif al-Niẓāmiyya, 1941-1945. Reprinted with added index volume: Beirut: Dār al-Kutub al'Ilmiyya, n.d.

Bukhārī. Șaḥịh. Numerous editions. Individual reports conventionally numbered after Ibn Hajar. Fath al-Bārī. Edited by Muhibb al-Dīn al-Khațīb. 14 vols. Cairo: al-Maṭba'a al-Salafiyya, 1380/196o.

Burton, John. The Sources of Islamic Law: Islamic Theories of Abrogation. Edinburgh: Edinburgh University Press, 199 o.

Calder, Norman. "Ikhtilâf and Ijmâc in Shâfi'î’s Risâla." Studia Islamica $5^{8}$ (1983): 55-81. Calder, Norman. Studies in Early Muslim Jurisprudence. Oxford: Clarendon Press, 1993. Cook, Michael. Early Muslim Dogma. Cambridge: Cambridge University Press, 1981. Al-Dārimì. Al-Sunan. Multiple editions, of which the best is now al-Musnad al-Jāmic. 
Edited by Nab̄̄l b. Hāshim ‘Abd Allāh al-Ghamrī. Beirut: Dār al-Bashā’ir al-Islāmiyya, 1434/2013.

Dickinson, Eerik. The Development of Early Sunnite hadīth Criticism. Islamic History and Civilization, Studies and Texts 38. Leiden: Brill, 2001.

Dirār b. 'Amr. Kitāb al-Tahrīsh. Edited by Hüseyin Hansu and Mehmet Keskin. Istanbul: Sharikat Dār al-Irshād and Beirut: Dār Ibn Ḥazm, 1435/2014.

El Shamsy, Ahmed. The Canonization of Islamic Law. Cambridge: Cambridge University Press, 2013.

Ess, Josef van. "L' autorité de la tradition prophétique dans la théologie mu'tazilite." In La notion d'autorité au Moyen Age, organized by George Makdisi, Dominique Sourdel and Janine Sourdel-Thomine, 211-226. Paris: Presses Universitaires de France, 1982.

Ess, Josef van. Theologie und Gesellschaft im 2. und 3. Jahrhundert Hidschra. 6 vols. Berlin: Walter de Gruyter, 1991-1995.

Fück, Johann. "Some Hitherto Unpublished Texts on the Mu'tazilite Movement from Ibn al-Nadīm's Kitāb-al-Fihrist." In Professor Muhammad Shafĩ Presentation Volume, edited by S.M. Abdullah, 51-74. Lahore: Majlis-e-Armughān-e-'Ilmī, 1955.

Gibb, Hamilton A.R. Muhammedanism, and edition. Oxford: Oxford University Press, 1962.

Al-Ḥākim al-Naysābūrī. An Introduction to the Science of Tradition: Being al-madkhal ilā márifat al-Iklil. Edited and translated by James Robson. Oriental Translation Fund, new series, 39. London: Luzac and Co., 1953.

Al-Hibri, Azizah. "Islam, Law and Custom: Redefining Muslim Women's Rights." American University Journal of International Law and Policy 12 (1997): 1-44.

Hildebrandt, Thomas. Neo-Mu'tazilismus? Intention und Kontext in modernen arabischen Umgang mit dem rationalistischen Erbe des Islam. Islamic Philosophy, Theology, and Science, Texts and Studies 77. Leiden: Brill, 2007.

Ibn 'Abd al-Barr. Al-Intiqā' fì Fad̄āil al-Thalātha al-A'imma al-Fuqahā’ Mālik wa-alShāfīi wa-Abì Hanīfa. Cairo: Maktabat al-Qudsī, 1350.

Ibn Abī Ḥātim. Kitāb al-Jarh wa-al-Ta'dīl. 9 vols. Hyderabad:Jam'iyyat Dā’irat al-Ma'ārif al-'Uthmāniyya, 136o-1371. Reprinted Beirut: Dār Ihyyā’ al-Turāth al-'Arab̄̄, n.d.

Ibn Hajar. Tabṣīr al-Muntabih bi-Taḥrīr al-Mushtabih. Edited by 'Alī Muḥammad alBijāwī and revised by Muḥammad 'Alī al-Najjār. Turāthunā. 4 vols. Cairo: al-Dār al-Mișriyya lil-Ta’lif wa-al-Tarjama, 1964?-1967. Reprinted: Beirut: al-Maktaba al'Ilmiyya, n.d.

Ibn Ḥajar. Tahdhīb al-Tahdhīb. 12 vols. Hyderabad: Majlis Dā’irat al-Ma'ārif al-Nizāamiyya, 1325-1327. Reprinted: Beirut: Dār Șādir, n.d.

Ibn Māja. Al-Sunan. Multiple editions. Individual reports conventionally numbered after the edition of Muhammad Fu’ād 'Abd al-Bāqī. 2 vols. Cairo: Dār Iḥyā' al-Kutub al-'Arabiyya, 1952-1954. 
Ibn al-Nadīm. Kitâb al-Fihrist. Edited by Gustav Flügel, with Johannes Roedigger and August Mueller. Leipzig: F.C.W. Vogel, 1872.

Ibn Sacd. Biographien. Edited by Eduard Sachau et al. 9 vols. in 15. Leiden: Brill, 19041940. = 9 vols. Beirut: Dār Șādir, 1957-1968.

Al-Ijlī. Tārīkh al-Thiqāt. Arranged by Ibn Ḥajar al-Haythamī and edited by 'Abd al-Mu'țī Qal'ajī. Beirut: Dār al-Kutub al-'Ilmiyya, 1405/1984.

Al-Jașșāṣ al-Rāzī. Al-Fuṣūl fì al-Ușūl, 2nd printing. Edited by 'Ujayl Jāsim al-Nashmī. Al-Turāth al-Islāmī 14. 4 vols. Kuwait: Wizārat al-Awqāf wa-al-Shu'ūn al-Islāmiyya, 1414/1994.

Juynboll, Gautier H.A. Muslim Tradition: Studies in Chronology, Provenance and Authorship of Early hadīth. Cambridge Studies in Islamic Civilization. Cambridge: Cambridge University Press, 1983.

Juynboll, Gautier H.A. "Muslim's Introduction to his Șaḥ̄ḥ, Translated and Annotated with an Excursus on the Chronology of fitna and bid'a." Jerusalem Studies in Arabic and Islam 5 (1984): 263-311.

Juynboll, Gautier H.A. Encyclopedia of Canonical Hadith. Leiden: Brill, 2007.

Khalīfa b. Khayyāț. Al-Tārīkh. Edited by Suhayl Zakkār. Ihyā̄ al-Turāth al-Qadīm 19. 2 vols. Damascus: Wizārat al-Thaqāfa, 1968.

Al-Khașșāf. Kitāb Aḥkām al-Awqāf. N.p.: Mațba'at Dīwān 'Umūm al-Awqāf al-Mișriyya, 1322/1904.

Al-Khațīb al-Baghdādī. Tārīkh Madīnat al-Salām. Edited by Bashshār 'Awwād Ma' rūf. 17 vols. Beirut: Dār al-Gharb al-Islāmī, 1422/2001.

Kohlberg, Etan. "Introduction [to the section on hadith]." In The Study of Shici Islam:History, Theology and Law, edited by Farhad Daftary and Gurdofarid Miskinzoda, $165^{-}$ 18o. The Institute of Ismaili Studies Shi'i Heritage series 2. London: I.B. Tauris, 2014. Al-Kulaynī. Al-Kāfí. Edited by 'Alī Akbar al-Ghaffārī and corrected by Muhammad alĀkhundī. 8 vols. Tehran: Dār al-Kutub al-Islāmiyya, 1389, 1391.

Lowry, Joseph E. Early Islamic Legal Theory: The Risāla of Muhammad ibn Idrīs al-Shāfiti. Studies in Islamic Law and Society 3o. Brill: Leiden, 2007.

Maḥmūd, 'Abd al Majīd. Abū Ja'far al-Ṭahāwī̄wa-Atharuhū fì al-Hadīth. Al-Maktaba al'Arabiyya. Cairo: al-Hay'a al-'Āmma lil-Kitāb, 1395/1975.

Mālik. Al-Muwațta'. Recension of Yahyā b. Yahyā. Numerous editions, of which the best is now that of Bashshār 'Awwād Ma'rūf. 2 vols. Beirut: Dār al-Gharb al-Islāmī, 1417/1997.

Martin, Richard C., and Mark R. Woodward with Dwi S. Atmaja. Defenders of Reason in Islam: Mu'tazilism from Medieval School to Modern Symbol. Oxford: Oneworld, 1997.

Melchert, Christopher. "Bukhārī and Early Hadith Criticism." Journal of the American Oriental Society 121 (2001): 7-19.

Melchert, Christopher. "Traditionist-Jurisprudents and the Framing of Islamic Law." Islamic Law and Society 8 (2001): 383-406. 
Melchert, Christopher. Ahmad ibn Hanbal. Makers of the Muslim World. Oxford: Oneworld, 2006.

Melchert, Christopher. "Whether to Keep Women out of the Mosque." In Authority, Privacy and Public Order in Islam, edited by B. Michalak-Pikulska and A. Pikulski, 59-70. Orientalia Lovaniensia analecta 148. Leuven: Peeters, 2006.

Melchert, Christopher. "The History of the Judicial Oath in Islamic Law." In Oralité et lien social au Moyen Âge (Occident, Byzance, Islam), edited by Marie-France Auzépy and Guillaume Saint-Guillain, 309-326. Centre de recherche d'histoire et civilisation de Byzance Monographies 29. Paris: ACHCByz, 2008.

Mernissi, Fatima. The Veil and the Male Elite. Translated by Mary Jo Lakeland. Boston: Addison-Wesley, 1991.

Muslim. Al-Jāmic al-Ṣaḥ̄h. Numerous editions. Individual reports conventionally numbered after edition of Muḥammad Fu’ād 'Abd al-Bāqì. 5 vols. (Cairo): ‘'̄sā al-Bābī al-Halabī wa-Shurakā'uh, 1374-1375/1955-1956.

Al-Nasā'ì. Al-Mujtabāa Numerous editions. Individual reports conventionally numbered after edition of Muhammad 'Ațā̄ Allāh al-Fūjayānī al-Amritsarī. Lahore: alMaktaba al-Salafiyya, 1376.

El-Omari, Racha. "Accommodation and Resistance: Classical Mu'tazilites on Hadīth." Journal of Near Eastern Studies 71 (2012): 231-256.

Rahman, Fazlur. Islamic Methodology in History. Central Institute of Islamic Research (Pakistan) 2. Karachi: Central Institute of Islamic Research, 1965.

Robson, James. "Hadīth." In Encyclopaedia of Islam, 2nd edition, vol. III, edited by P. Bearman, Th. Bianquis, C.E. Bosworth, E. van Donzel, and W.P. Heinrichs. Leiden: Brill, 1971.

Rosenthal, Franz. A History of Muslim Historiography, and revised edition. Leiden: Brill, 1968.

Ṣālị̣ b. Aḥmad. Masāil al-Imām Aḥmad b. Hanbal. Edited by Ṭāriq b. 'Awaḍ (sic) Allāh b. Muhammad. Riyadh: Dār al-Wațan, 1420/1999.

Sánchez, Ignacio. "Shāfiī Hermeneutics and Qur’anic Interpretation in al-Jāḥiẓ’s Kitāa al-'Uthmāniyya." In Tafsīr and Islamic Intellectual History, edited by Andreas Görke and Johanna Pink, 187-221. Qur’anic Studies series 12. London: Oxford University Press, 2014 .

Schacht, Joseph. The Origins of Muhammadan Jurisprudence. Oxford: Clarendon Press, 1950.

Al-Shāfìì. The Epistle on Legal Theory. Edited and translated by Joseph E. Lowry. Library of Arabic Literature. New York: New York University Press, 2013.

Al-Shāfíī. Al-Umm. Edited by Rif'at Fawzī 'Abd al-Muțtalib. 11 vols. Al-Manșūra: Dār alWafā', 1422/2001. 2nd printing: 1425/2004.

Al-Shaybānī. Kitāa al-Hujja 'alā Ahl al-Madīna. Edited by Abū al-Wafā' al-Afghānī et al. Silsilat al-Maṭbū'āt 1. 4 vols. Hyderabad: Mațba'at al-Ma'ārif al-Sharqiyya, 1385/1965. Reprinted: Beirut: ‘Ālam al-Kutub, 1403/1983. 
Spectorsky, Susan A. “Aḥmad Ibn Ḥanbal's Fiqh." Journal of the American Oriental Society 102 (1982): 461-465.

Al-Tabarī. The History of al-Ṭabarī 13: The Conquest of Iraq, Southwestern Persia, and Egypt. Translated by Gautier H.A. Juynboll. Bibliotheca Persica and sunY Series in Near Eastern Studies. Albany: State University of New York Press, 1989.

Al-Ṭahāwī. Sharḥ Máānī al-Āthār. Edited by Muḥammad Sayyid Jād al-Ḥaqq. 4 vols. Cairo: Maṭba'at al-Anwār al-Muhammadiyya, n.d.

Al-Ṭahāwī. Sharh Mushkil al-Āthār. Edited by Shu'ayb al-Arna'ūṭ. 16 vols. Beirut: Mu'assasat al-Risāla, 1415/1994.

Al-Tirmidhī. Kitāb Tlal al-Tirmidhī al-Kabīr. Arranged by Abū Ṭālib al-Qāḍī and edited by Șubhị̄ al-Sāmarrāīè, Abū al-Macāṭ̄ al-Nūrī and Maḥmūd Muhammad Khalīl alȘâ̄ì̄ī. Beirut: 'Ālam al-Kutub and Maktabat al-Nahḍa al-'Arabiyya, 1409/1989.

Al-Tirmidhī. Al-Jāmi al-Șaḥ̄h. Numerous editions. Individual reports conventionally numbered after edition of Aḥmad Muhammad Shākir, Muḥammad Fu'ād 'Abd alBāqī and Ibrāhīm 'Ațwah 'Iwaḍ. 5 vols. Cairo: Muṣțafā al-Bābī al-Ḥalabī wa-Awlāduh, 1356-1395/1937-1975.

Wakīc. Akhbār al-Quḍāt. Edited by 'Abd al-'Azīz Mușțafā al-Marāghī. 3 vols. Cairo: Mațba'at al-Istiqāma, 1366-1369/1947-195o.

Yahia, Mohyddin. Šăfic et les deux sources de la loi islamique. Turnhout: Brepols, 2009.

Zahniser, A.H. Mathias. "Source Criticism in the 'Uthmāniyya of al-Jāhiiz." Muslim World 70 (1980): 131-141.

Zysow, Aron. The Economy of Certainty: An Introduction to the Typology of Islamic Legal Theory. Resources in Arabic and Islamic Studies 2. Atlanta: Lockwood, 2013. 